\title{
Gender Differences in Decision-making and Leadership: Evidence from Armenia
}

http://doi.org/10.21272/bel.4(1).6-16.2020

Diana Minasyan, ORCID: https://orcid.org/0000-0001-5493-7454

$\mathrm{PhD}$, Lecturer at the Department of Accounting and Auditing, Armenian State University of Economics; Chief accountant at CJSC "Factory of reinforced bridge concrete structures", the Republic of Armenia

Gayane Tovmasyan, ORCID: https://orcid.org/0000-0002-4131-6322

$\mathrm{PhD}$, Senior Researcher at "AMBERD” Research Center of the Armenian State University of Economics; Lecturer at the Armenian State University of Economics; Lecturer at the Public Administration Academy, the Republic of Armenia

\begin{abstract}
This paper summarizes the arguments and counterarguments within the scientific discussion on the issue of gender differences in decision-making and leadership positions. The main purpose of the research is to find out if there are gender differences in decision-making styles, career development, and leadership and reveal the main causes. A systematization of literary sources on the issue of gender differences in the decision-making process indicates that there are real differences: women are more sensitive, men are overconfident, men tend to be leaders more than women. Investigation of the topic proves that in leadership positions men are promoted more than women are, also there is a payment gap between genders. Analysis in the paper is carried out in the following logical sequence: the statistical data available has been analyzed, and then a survey is done, which reveals some issues of gender differences in leadership and decision-making in workplaces in Armenia. Based on the generalization of the results, the differences in decision-making are determined and the corresponding conclusions are drawn. Methodological tools of the research methods were analysis and synthesis of the available data, survey, and statistical methods: cross-tabulation with Pearson Chi-square testing, which proves that there are significant relationships between some factors. The paper presents the results of an empirical analysis, which shows that in Armenia women and men make decisions differently, women have less opportunities for career promotion. The survey reveals that women make decisions in groups, men - alone. The main characteristics of women during the decision-making process are: analytical thinking, consulting, honesty and intuitive thinking. The survey also reveals the main reasons why men are appointed to leadership positions and the main stereotypes that hinder women's career advancement. The results of the research can be useful for state bodies, labor market, organizations, educational institutions, researchers, etc.
\end{abstract}

Keywords: gender, inequality, decision-making, leadership, Chi-square testing, survey, gender differences.

JEL Classification: D7, J16.

This work is licensed under a Creative Commons Attribution 4.0 International License

Cite as: Minasyan, D., Tovmasyan, G. (2020). Gender Differences in Decision-making and Leadership: Evidence from Armenia. Business Ethics and Leadership, 4(1), 6-16. http://doi.org/10.21272/bel.4(1).616.2020.

(C) The Authors, 2020. This article is published with open access at Sumy State University.

\section{Introduction}

The effectiveness of work depends mainly on the workers. Depending on gender, the decisions made in the organization may have a different level of efficiency. Nowadays, gender inequality issues really matter in workplaces. In many organizations, the salary of women is lower. They also have less opportunities to be promoted. The purpose of the article is to reveal the gender differences in working and decision-making process that impact the effectiveness of management and the overall performance of the organization. In the article current data available from the Statistical Committee of the RA are analyzed, the data of Armenia in the Gender Gap report are discussed, the Gender pay gap report and Human development index are analyzed, besides a survey is done among 100 participants, for revealing their experiences and faced problems. The analyses show that there are more women workers in some sectors of the economy, and in some sectors male 
workers exceed. Besides, in all areas, women are paid less than men are. The survey also reveals the main differences in decision-making styles, career promotion.

\section{Literature review}

Here we will discuss some aspects of gender differences in the working process, leadership and decisionmaking.

Women are much more interested in relationships than tasks. Men prefer to build relationships as they're doing the task. Women often like to discuss options out loud before reaching a decision. Men seem to prefer quiet contemplation. In terms of communication, women not only like to discuss things, but nonverbal communication may include lots of eye-to-eye contact, head nodding to indicate agreement, and standing face to face. For some men, some of these things can be threatening. Men talking together will very often be side to side at an angle, a position that's more comfortable for them. Women may interpret this as being secretive or uninterested. Another area where there are significant gender differences in decision-making is in the area of asking others for help. Women make this decision much more quickly than men do. For example, a study was done on employees whose PCs at work became infected with spyware. $64 \%$ of women called the IT department for help. Only 30 percent of men did so (Gender Differences in Decision Making).

Another study was done by Muyinudeen and Elsadig (2008) in Malaysia and the results showed that the "Malaysian male managers were more in directive, strategic and risk-taking decision-making styles, whereas their female managers more in democratic, participative, normal-adoptive, consensus, and hesitant decision-making styles than their counterparts. The Malaysian entrepreneurs were more risktakers than their female counterparts in general".

A study done by Wing et al. (2010) showed that women spend more time on making a decision than males did.

A recent study done in Kenya examined the effect of board diversity and firm performance and the results showed that the relationship between gender and firm performance was positive, this means that gender diverse boards perform better as measured by ROA (Ombaba, 2016).

According to the 2009 McKinsey Report, women's leadership style, unlike men's style, is more people-based and can be described as role modeling. It was also stated that women give clear expectations and rewards. Similarly, a study from 2012 prepared by Zenger Folkman demonstrates that women are rated as more competent when taking initiative, self-development, honesty, and driving for results into account.

Women are more risk-averse (Weber, Blais, and Betz, 2002), have higher social sensitivity, and react by feeling. Men are more overconfident, more optimistic, and react by action (Patel, 2013). Women react more emotionally than men do, especially in negative situations. So, when an immediate response is required, men react by action whereas a women's reaction is to feel (Gorska, 2016).

Many researchers relate masculinity with a task-oriented leadership style and femininity with a relationshiporiented leadership style (Shanmugam et al.).

According to Eagly \& Johannesen-Schmidt (2001), men are more assertive, ambitious, aggressive, independent, self-confident, and competitive in the decision-making and working process. Women are more affectionate, helpful, kind, sympathetic, interpersonally sensitive, and gentle. In work situations, women accept others' positions, support others, and contribute to the solution of relational and interpersonal problems.

Another interesting research suggests that women don't rely on intuition more often than men, thus women are just as data-driven and analytical as men, if not more so. In a sample of 32 studies that looked at how men and women thought about a problem or made a decision, 12 of the studies found that women adopted an analytical approach more often than men, meaning that women systematically turned to the data, while men were more inclined to go with their gut, hunches, or intuitive reactions. The other 20 studies found no difference between men's and women's thinking styles. Not a single study found that women tended to be more intuitive in their decision-making styles (Caprino, 2016).

\section{Methodology and research methods}

The main purpose of the research is to analyze gender differences in working and decision-making processes that impact the effectiveness of management and the overall performance of the organization. 
To achieve this purpose, we have analyzed the same issues available in the literature. Besides, the current state in Armenia was analyzed. Also, a sociological survey was carried out among the workforce in Armenia, to find out how they are involved in decision-making, are there any differences in that process depending on their gender, etc.

Thus, the main methods were: analysis and synthesis, quantitative and qualitative methods, such as statistical method, survey.

The main results were based on the sociological survey among the population. The survey results were analyzed by statistical methods. A database was created, and the key results were obtained by using Crosstabulations with Pearson Chi-square coefficient testing (setting significance level $\alpha=0.05$ ).

\section{Discussion}

Gender differences in workplaces, leadership positions, and even salary rates are existing in the world. Some interesting facts are stated in the Gender Pay Gap. Between January 2016 and February 2018, over 2 million people participated in PayScale's online salary survey. They provided demographic information and information about the industry, occupation, location and other factors. Based on the data the Gender Pay Gap report was processed. According to it, where is a significant difference in how men and women are paid. They analyze uncontrolled and controlled gender pay gaps. The uncontrolled gender pay gap is the ratio of median earnings of all women to all men, which has decreased by $\$ 0.05$ since 2015. Anyhow, in 2019 women still make only 77.9 cents for every dollar men make, this means that the median salary of women is 22 percent lower than the median salary of men. The controlled gender pay gap takes into account many factors such as job title, years of experience, industry, and location. In this case, the only difference between workers is their gender. It has shrunk by just $\$ 0.008$ since 2015 , so women now make 97.8 cents for every dollar earned by men. How this difference is explained? It is explained using the opportunity gap, which means that women are less likely to hold higher-level, high-paying jobs than men are. Women also move up the career ladder slower compared to men. An analysis showed that at the beginning of career (age group 20-29), 74 percent of men and 75 percent of women are in personally donor roles. A very small proportion of women reach the manager or higher level by the midst of their career. At the age range of 30-44, which is considered as mid-career, 47 percent of men are usually managers or higher, however, only 40 percent of women reach this level. At the age of older 45 , which is late-career, 57 percent of men are working as managers or at higher levels, and only 41 percent of women reach this level. And it is very interesting that only three percent of women reach an executive-level position, compared to eight percent of men.

Another interesting issue was revealed during the salary survey when a great part of workers did not agree that they were paid reasonably by their employer. Women of every race have a more negative viewpoint on the fairness of payment compared to white men.

The report shows that women are paid less compared to men of every occupation. Women are mostly occupied in the spheres of healthcare, personal care \& service, education, training, office \& administrative support, and community \& social services. Men are mostly occupied in construction, installation and maintenance, architecture \& engineering, computer science and transportation (Women are still paid less in 2019).

The report states that women are more likely to be unemployed for longer periods of time for caring for children or other family members (The state of the Gender Pay Gap in 2018).

According to the Human development index of UNDP, Armenia was the $83^{\text {rd }}$ with the index of 0.755 . The Gender development index was 0.969 , the Gender inequality index -0.262 . Only $18.1 \%$ of seats in parliament were held by women (Human Development Indices and Indicators, 2018).

Table 1. HDI of Armenia, 2018

\begin{tabular}{|c|c|c|c|c|c|c|c|}
\hline & \multirow[t]{2}{*}{$\begin{array}{c}\text { Human } \\
\text { development } \\
\text { index (HDI) }\end{array}$} & \multirow[t]{2}{*}{ HDI rank } & \multirow[t]{2}{*}{$\begin{array}{c}\text { Gender } \\
\text { development } \\
\text { index }\end{array}$} & \multirow[t]{2}{*}{$\begin{array}{l}\text { Gender } \\
\text { inequality } \\
\text { index }\end{array}$} & \multirow{2}{*}{$\begin{array}{c}\text { Share of seats } \\
\text { in parliament, } \\
\text { (\% held by } \\
\text { women) }\end{array}$} & \multicolumn{2}{|c|}{$\begin{array}{c}\text { Labour force } \\
\text { participation rate ( } \% \\
\text { ages } 15 \text { and older) }\end{array}$} \\
\hline & & & & & & female & male \\
\hline Armenia & 0.755 & 83 & 0.969 & 0.262 & 18.1 & 51.4 & 70.6 \\
\hline
\end{tabular}

Source: Human Development Indices and Indicators, 2018

Another index is the Global Gender Gap Index, introduced by the World Economic Forum in 2006. In the report of 2018, Armenia was the $98^{\text {th }}$ with 0.678 scores (The Global Gender Gap Report, 2018). 
Table 2. Global Gender Gap Index of Armenia, 2018

\begin{tabular}{|l|c|c|c|c|c|c|}
\hline & Rank & Score & Average & Female & Male & f/m \\
\hline Economic participation and opportunity & $\mathbf{7 3}$ & $\mathbf{0 . 6 7 5}$ & $\mathbf{0 . 5 8 6}$ & - & - & - \\
\hline Labor force participation & 84 & 0.762 & 0.669 & 5707 & 75.7 & 0.76 \\
\hline Wage equality for similar work (survey) & 38 & 0.709 & 0.645 & - & - & 0.71 \\
\hline Estimated earned income (PPP, US\$) & 99 & 0.545 & 0.510 & 6.926 & 12.714 & 0.54 \\
\hline Legislators, senior officials and managers & 86 & 0.419 & 0.329 & 29.5 & 70.5 & 0.42 \\
\hline Professional and technical workers & 1 & 1.000 & 0.753 & 61.6 & 38.4 & 1.60 \\
\hline Educational attainment & $\mathbf{3 5}$ & $\mathbf{1 . 0 0 0}$ & $\mathbf{0 . 9 4 9}$ & - & - & - \\
\hline Literacy rate & 49 & 0.999 & 0.882 & 99.7 & 99.8 & 1.00 \\
\hline Enrolment in primary education & 69 & 0.999 & 0.978 & 92.0 & 92.1 & 1.00 \\
\hline Enrolment in secondary education & 1 & 1.000 & 0.967 & 88.1 & 87.5 & 1.01 \\
\hline Enrolment in tertiary education & 1 & 1.000 & 0.939 & 58.7 & 46.1 & 1.27 \\
\hline Health and survival & $\mathbf{1 4 8}$ & $\mathbf{0 . 9 3 9}$ & $\mathbf{0 . 9 5 5}$ & - & - & - \\
\hline Sex ratio at birth & 148 & 0.886 & 0.921 & - & - & 0.89 \\
\hline Healthy life expectancy & 1 & 1.060 & 1.034 & 68.7 & 63.6 & 1.08 \\
\hline Political empowerment & $\mathbf{1 1 5}$ & $\mathbf{0 . 0 9 9}$ & $\mathbf{0 . 2 2 3}$ & - & - & - \\
\hline Women in parliament & 96 & 0.221 & 0.284 & 18.1 & 81.9 & 0.22 \\
\hline Women in ministerial positions & 109 & 0.125 & 0.208 & 11.1 & 88.9 & 0.12 \\
\hline Years with female head of state (last 50) & 71 & 0.000 & 0.189 & 0.0 & 50.0 & 0.00 \\
\hline
\end{tabular}

Source: The Global Gender Gap Report 2018

So, there are problems with health and survival index, political empowerment index, Labor force participation, Estimated earned income (PPP, US\$), Legislators, senior officials, and managers sub-indexes.

Now, we will analyze the salaries of men and women by institutional sectors in Armenia. As we can notice, women are more exploited in the public sector rather than in the non-public sector. In the public sector, men are paid $32.9 \%$ more than women. In the non-public sector, the difference is $28.6 \%$. And all this disparity is displayed in everyday life, whereas the state has an obligation to pursue a policy that protects the rights of women and gender equality. Additionally, we have to point out that the $86^{\text {th }}$ article of the Constitution of Armenia states that one of the main objectives of state policy in the economic, social and cultural spheres shall be promoting actual equality between women and men. However, equal payment for the equal job is still an issue and the payment gap between men and women is still an everyday occurrence. Moreover, this disparity is more obvious in the public sector.

Table 3. Average Monthly Nominal Wages/Salaries by Institutional Sectors of Economy, 2017

\begin{tabular}{|l|r|r|r|}
\hline & $\begin{array}{r}\text { Women } \\
\text { (AMD) }\end{array}$ & $\begin{array}{r}\text { Men } \\
\text { (AMD) }\end{array}$ & $\begin{array}{r}\text { W/M } \\
\mathbf{\%}\end{array}$ \\
\hline Total & $\mathbf{1 4 3 0 1 6}$ & $\mathbf{2 1 1 ~ 7 2 0}$ & $\mathbf{6 7 . 5}$ \\
\hline Public & 131885 & 196595 & 67.1 \\
\hline Non-public & 157695 & 220937 & 71.4 \\
\hline
\end{tabular}

Source: Women and Men in Armenia 2018 Statistic Booklet

The difference in average nominal wages (earnings) of women and men decreased by 8.3 percentage points over the last ten years. In 2017, the women's earnings amounted to $67.5 \%$ of men's earnings, so the gender pay gap amounts $32.5 \%$. Even there is progress but still, the pay gap amount is too enormous, and numbers are not encouraging.

However, in the executive branch, which is not regulated by any legislative norms there was only one female minister, and there were only 2 female deputy ministers from 57 deputy ministers.

Table 4. Ministries and Deputy Ministers, 2017

\begin{tabular}{|l|r|r|r|r|}
\hline & $\begin{array}{r}\text { Women } \\
\text { (Person) }\end{array}$ & $\begin{array}{r}\text { Men } \\
\text { (Person) }\end{array}$ & $\begin{array}{r}\text { Women } \\
(\boldsymbol{\%})\end{array}$ & $\begin{array}{r}\text { Men } \\
(\boldsymbol{\%})\end{array}$ \\
\hline Total & $\mathbf{3}$ & $\mathbf{7 2}$ & $\mathbf{4}$ & $\mathbf{9 6}$ \\
\hline Ministers & 1 & 17 & 5.6 & 94.4 \\
\hline Deputy Ministers & 2 & 55 & 3.5 & 96.5 \\
\hline
\end{tabular}

Source: Women and Men in Armenia 2018 Statistic Booklet

It should be noted that there were no other females among the heads of 10 provinces and among the mayors of 49 cities in 2017, however among 502 heads of local communities 8 were female. So, to sum up, we can affirm that women have little involvement in state and local governance. 
Table 5. Marz Governor (Marzpet) Head and Council Members of Community, 2017

\begin{tabular}{|l|r|r|r|r|r|}
\hline & Total & $\begin{array}{r}\text { Women } \\
\text { (Person) }\end{array}$ & $\begin{array}{r}\text { Men } \\
\text { (Person) }\end{array}$ & $\begin{array}{r}\text { Women } \\
(\%)\end{array}$ & $\begin{array}{r}\text { Men } \\
(\%)\end{array}$ \\
\hline Marzpet (Head of province) & 10 & - & 10 & - & 100 \\
\hline Head of community & 502 & 8 & 494 & 1 & 1.6 \\
\hline Of which; Yerevan city & 1 & - & 3429 & 10.5 & 88.4 \\
\hline Council members of community & 3830 & 401 & 45 & 30.8 & 100 \\
\hline Of which; Yerevan city & 65 & 20 & 69.5 \\
\hline
\end{tabular}

Source: Women and Men in Armenia 2018 Statistic Booklet

There are many women among the middle and low-skilled civil service employment. Among junior posts, $72 \%$ are female, among leading posts only 59\%, and so higher we ascend - less women there are in power positions, among chief posts $48 \%$, and among highest posts only $15 \%$. It should be noted, that as greater is the responsibility and participation in the decision-making process, as lower is the number of women, and their involvement in it.

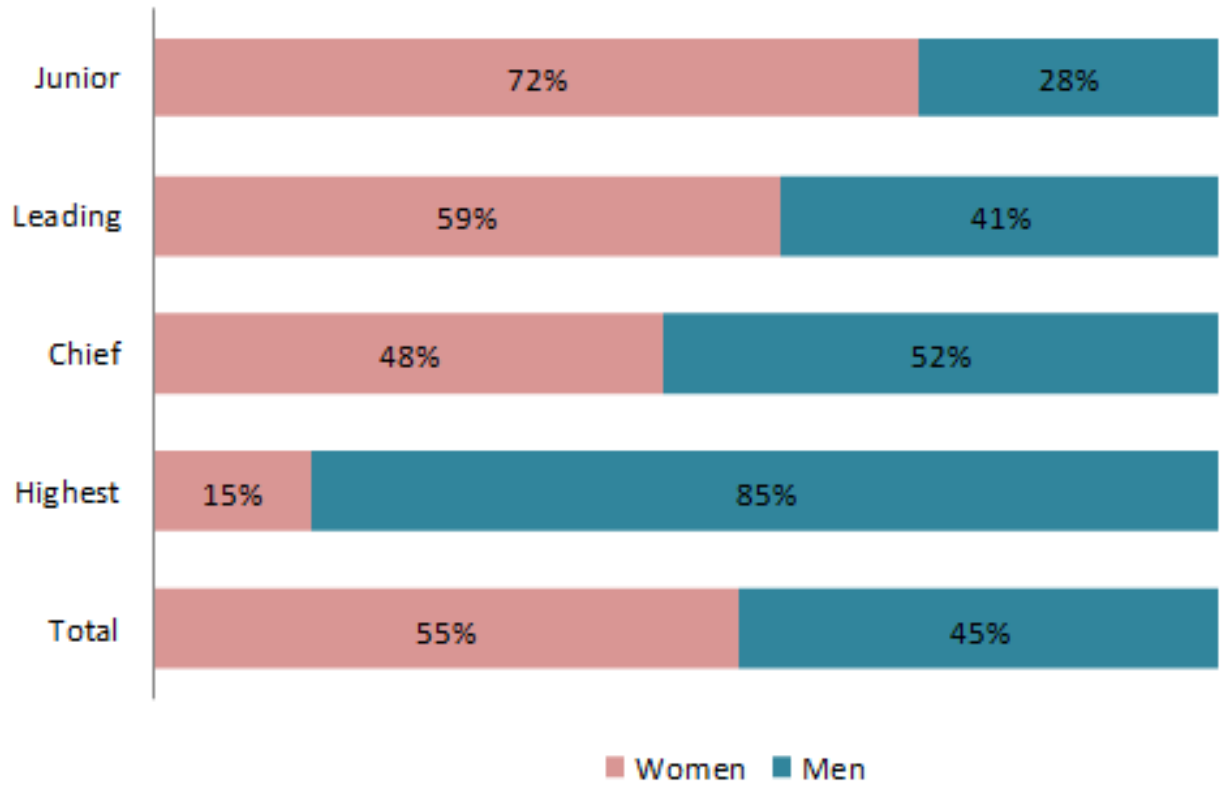

Figure 1. Posts of the Civil Service of RA, 2017

Source: Women and Men in Armenia 2018 Statistic Booklet

There are various laws that protect women's rights in gender equality. Article 30 of the Armenian Constitution states that men and women have equal rights.

The National Assembly of the Republic of Armenia has adopted a law in 2013 about "The Insurance of Equal Rights and Equal Opportunities for Women and Men" (The low of the Republic of Armenia "The Insurance of Equal Rights and Equal Opportunities for Women and Men" 2013). In another document "The Electoral Code of The Republic of Armenia", there is a provision article 83 that states that the number of representatives in the National Assembly of the Republic of Armenia each gender should not exceed 70 percent (The low of the Republic of Armenia "The Electoral Code of The Republic of Armenia", 2016), so in 2017 from 105 members only 19 were females. In 2018 from 132 deputies only 32 elected are women.

It should also be noted that on 19 September 2019 the Government of The Republic of Armenia approved a gender strategic plan for the implementation of gender policies in the Republic of Armenia for 2019-2023 (Gender strategic plan 2019-2023).

The aforementioned norms are also regulated by international documents that were ratified by the Republic of Armenia (United Nations, ILO, WTO, CoE, EU). Hence, there are quite a few laws and international documents signed by the Republic of Armenia, there are also a number of obstacles and challenges on the path to gender equality.

\section{Results}

In order to find out how gender differences impact the decision-making process, we have conducted a survey among 100 workers and managers during November 2019. The results are as follows: $29 \%$ of the respondents were male, $71 \%$ - female. $63 \%$ were $26-39$ years old, $27 \%$ - up to 25 years old. $67 \%$ had higher education, $35 \%$ were working in the education sphere, $19 \%$ - in the financial sector, $15 \%$ - in the public sector, etc. 
Table 6. Main characteristics of survey participants

\begin{tabular}{|l|l|}
\hline \multicolumn{2}{|c|}{ Quantity/ Share in the total, \% } \\
\hline Gender & 71 \\
\hline Female & 29 \\
\hline Male & 27 \\
\hline up to 25 years old & 63 \\
\hline 26-39 years old & 8 \\
\hline $40-55$ years old & 2 \\
\hline $56-65$ years old & - \\
\hline 66 and older & 67 \\
\hline Education & 26 \\
\hline Higher & 7 \\
\hline Post-graduate & - \\
\hline Vacational & 19 \\
\hline Secondary & 10 \\
\hline Occupation & 8 \\
\hline Financial sector & 35 \\
\hline Production & 15 \\
\hline Tourism & 8 \\
\hline Education sphere & 5 \\
\hline Public sphere & \\
\hline Other & \\
\hline
\end{tabular}

Source: Own adjustment based on the survey results

The $60 \%$ of the respondents were workers, $52 \%$ answered that they make decisions in groups, and according to $50 \%$ the gender has no impact on the effectiveness of decision-making.

Table 7. Some data of survey participants

\begin{tabular}{|c|c|}
\hline & Quantity \\
\hline \multicolumn{2}{|l|}{ The position held } \\
\hline Worker & 60 \\
\hline lower lever manager & 7 \\
\hline middle level manager & 24 \\
\hline high level manager & 9 \\
\hline \multicolumn{2}{|l|}{ Decision-making in workplaces } \\
\hline Alone & 27 \\
\hline In groups & 53 \\
\hline both, alone and in groups & 7 \\
\hline I do not participate in the decision-making process & 13 \\
\hline \multicolumn{2}{|c|}{ Do you think that gender differences affect decision-making in any way? } \\
\hline yes, it affects & 10 \\
\hline it does not affect & 50 \\
\hline Partially & 36 \\
\hline it is difficult to answer & 4 \\
\hline \multicolumn{2}{|c|}{ What difficulties do female leaders face in governance? (participants could mention more than one option) } \\
\hline discriminatory treatment & 35 \\
\hline contempt, neglect & 10 \\
\hline not obeying & 19 \\
\hline Inexperience & 15 \\
\hline do not face any difficulties & 35 \\
\hline Other & 8 \\
\hline \multicolumn{2}{|l|}{ Do men face the same difficulties? } \\
\hline Yes & 15 \\
\hline No & 25 \\
\hline Partially & 35 \\
\hline I do not know & 25 \\
\hline \multicolumn{2}{|c|}{ How long does it take for men and women to make a decision? } \\
\hline Women spend less time & 20 \\
\hline Men spend less time & 24 \\
\hline Equal & 19 \\
\hline I do not know & 37 \\
\hline
\end{tabular}

Source: Own adjustment based on the survey results

The respondents who answered that gender differences affect the decision-making process gave different explanations. Some mentioned that women have a better impact on decisions, people treat more severely to the decisions made by women, than men, besides women have a high level of intuition, which helps in some cases. 
According to $35 \%$ of the respondents, female leaders do not face any difficulties in governance, while $35 \%$ mentioned discriminatory treatment. According to $24 \%$ of the participants, men spend less time to make a decision.

To the question "Which of the following works are typical for women and which are typical for men?"' the respondents answered the following way.

Table 8. Works typical for men and women

\begin{tabular}{|l|c|c|c|c|}
\hline & Typical for women & Typical for men & $\begin{array}{c}\text { Typical for both } \\
\text { women and men }\end{array}$ & $\begin{array}{c}\text { It is difficult to } \\
\text { answer }\end{array}$ \\
\hline Waiter & 48 & 40 & 41 & 1 \\
\hline Truck-worker & 3 & 90 & 4 & - \\
\hline Builder & 3 & 89 & 5 & - \\
\hline Concierge & 6 & 89 & 44 & - \\
\hline Doctor & 46 & 46 & 40 & - \\
\hline Hairdresser & 57 & 33 & 29 & - \\
\hline Tailor & 64 & 28 & 21 & - \\
\hline Driver & 17 & 71 & 41 & - \\
\hline Teacher & 54 & 30 & 44 & - \\
\hline Director & 41 & 41 & 41 & - \\
\hline Minister & 32 & 50 & 32 & 1 \\
\hline Prime minister & 24 & 59 & 30 & 1 \\
\hline President & 24 & 59 & 35 & - \\
\hline Ambassador & 32 & 54 & 35 & - \\
\hline Mayor & 24 & 55 & 40 & - \\
\hline Judge & 36 & 51 & 42 & - \\
\hline Lawyer & 39 & 46 & 32 & - \\
\hline Programmer & 29 & 59 & 41 & \\
\hline Marketing expert & 50 & 34 & 34 & - \\
\hline Designer & 61 & 32 & 39 & \\
\hline Accountant & 51 & 35 & & - \\
\hline
\end{tabular}

Source: Own adjustment based on the survey results

As it is seen from the table, people think that for example truck-workers, builders, concierges, drivers are less typical for women. And even among all respondents where $71 \%$ were females, they all think that top positions with huge responsibilities and with the independence of decision-making such as a prime minister, a president, a mayor, ambassadors should be held by males.

People also mentioned the main features that characterize them during making a decision. The most mentioned features are: analytical thinking, honesty, consulting, balance, flexibility, intuitive thinking.

Table 9. Main characteristics of people during the decision-making process (participants could mention more than one option)

\begin{tabular}{|l|c|c|c|c|c|}
\hline \multicolumn{1}{|c|}{ Characteristics } & Quantity & Women & Men & Women, \% & Men, \% \\
\hline High control & 32 & 19 & 13 & $27 \%$ & $\mathbf{4 5 \%}$ \\
\hline Analytical thinking & 65 & 41 & 24 & $\mathbf{5 8 \%}$ & $\mathbf{8 3 \%}$ \\
\hline Competitive thinking & 24 & 13 & 11 & $18 \%$ & $\mathbf{3 8 \%}$ \\
\hline Imperative style & 7 & 5 & 2 & $\mathbf{5 2 \%}$ & $\mathbf{4 1 \%}$ \\
\hline Consulting & 49 & 37 & 72 & $\mathbf{4 1 \%}$ & $24 \%$ \\
\hline Intuitive thinking & 36 & 29 & 2 & $14 \%$ & $7 \%$ \\
\hline Interpersonal orientation & 12 & 10 & 7 & $25 \%$ & $24 \%$ \\
\hline Task orientation & 25 & 18 & 22 & $31 \%$ & $28 \%$ \\
\hline Kindness & 30 & 22 & $\mathbf{4 9 \%}$ & $\mathbf{6 9 \%}$ \\
\hline Honesty & 55 & 35 & 8 & $27 \%$ & $28 \%$ \\
\hline Compassionate & 27 & 19 & 3 & $1 \%$ & $10 \%$ \\
\hline Aggression & 4 & 1 & 9 & $7 \%$ & $31 \%$ \\
\hline Ambitious & 14 & 5 & 12 & $25 \%$ & $41 \%$ \\
\hline Independence & 30 & 18 & 15 & $14 \%$ & $\mathbf{5 2 \%}$ \\
\hline Confidence & 25 & 10 & 9 & $14 \%$ & $31 \%$ \\
\hline Energetic & 19 & 10 & 13 & $28 \%$ & $\mathbf{4 5 \%}$ \\
\hline Determination & 33 & 20 & 13 & $21 \%$ & $\mathbf{4 5 \%}$ \\
\hline Tranquility & 28 & 15 & 15 & $30 \%$ & $\mathbf{5 2 \%}$ \\
\hline Flexibility & 36 & 21 & 19 & $35 \%$ & $\mathbf{6 6 \%}$ \\
\hline Balanced & 44 & 25 & 1 & $8 \%$ & $3 \%$ \\
\hline Impatientce & 7 & 6 & 9 & $13 \%$ & $17 \%$ \\
\hline Subjectivity & 14 & 9 & & & \\
\hline
\end{tabular}

Source: Own adjustment based on the survey results 
From Table 9 it can be concluded that the main characteristics of men during the decision-making process are: analytical thinking, balanced, honesty, confidence, flexibility, high control, tranquility, determination, consulting and competitive thinking.

The main characteristics of women during the decision-making process are: analytical thinking, consulting, honesty and intuitive thinking.

Compared to women, the following features are more characteristic to men during the decision-making: high control, analytical thinking, competitive thinking, honesty, aggression, ambitious, independence, confidence, energetic, determination, tranquility, flexibility, balanced, subjectivity.

Compared to men, the following features are more characteristic to women during decision-making: consulting, intuitive thinking, interpersonal orientation, kindness, impatience.

To the question "Why are men appointed to leadership positions?" the respondents mainly mentioned that men don't deal with home affairs, don't go on vacation connected with child birth, they orient quickly and are more nimble. Among other options mainly mentioned that it is because of national mentality, public perception, there is discrimination against women and it is accepted in our society that women are more impulsive, have wider interests and often want to devote their time to the family than to long and responsible work. People also mentioned that men are more inclined to appoint men as leaders and that maybe there is a relatively low share of female specialists in a specific field.

Table 10. The reasons for men to be appointed to leadership positions (participants could mention more than one option)

\begin{tabular}{|l|c|}
\hline \multicolumn{1}{|c|}{ Quantity } & Quantity \\
\hline They are smarter & 9 \\
\hline They are more nimble & 6 \\
\hline They are more capable & 22 \\
\hline they quickly orient & 8 \\
\hline they are more organized & 33 \\
\hline don't go on vacation connected with child birth & 36 \\
\hline they are not dealing with home affairs & 17 \\
\hline I don't know & 19 \\
\hline Other & \\
\hline
\end{tabular}

Source: Own adjustment based on the survey results

45 percent of respondents think that more women are needed in the management sphere. Among the other options mainly mentioned:

Quantity is not important, quality is important.

Gender should not be a decisive factor; we need professional, smart and knowledgeable people in the management sphere, who will be able to perform the duties.

If they are professionals, then yes.

Women are very much needed in every field.

Table 11. More women are needed in the management sphere

\begin{tabular}{|l|c|}
\hline \multicolumn{1}{|c|}{ Options } & Quantity \\
\hline I totally agree & 45 \\
\hline I do not agree & 19 \\
\hline What we have now is enough & 17 \\
\hline Other & 19 \\
\hline
\end{tabular}

Source: Own adjustment based on the survey results

According to the respondents, the following stereotypes hinder women's career advancement.

Table 12. What are the stereotypes that hinder women's career advancement? (participants could mention more than one option)

\begin{tabular}{|l|c|}
\hline \multicolumn{1}{|c|}{ Options } & Quantity \\
\hline Woman is for staying at home and cooking & 30 \\
\hline Woman must be obedient & 34 \\
\hline Woman has no right to have her own opinion & 18 \\
\hline Woman is for having a baby & 28 \\
\hline Without a man, a woman cannot succeed & 28 \\
\hline Nothing hinders & 39 \\
\hline other & 10 \\
\hline
\end{tabular}

Source: Own adjustment based on the survey results 
Among the other options people mentioned are the following:

A woman should not tell men what to do.

The Armenian mentality.

I think there are not stereotypes, babies are more connected to the mother, the mother feeds the baby, and it is normal that the woman gives more time to the family.

Women are more sensitive, and sometimes decisions may be affected.

$>$ Women can be very good leaders, but many people in our society (both men and women) will not want to obey them.

$67 \%$ of the respondents said that they have never lost their work progress because of their gender, $17 \%$ did not know really, only $16 \%$ said yes.

To find out if gender or occupation has any influence on decision-making, we must define some hypotheses and check them.

1. Relationship between gender and decision-making in workplaces.

H1: There is a significant relationship between gender and decision-making in workplaces.

H0: There is no significant relationship between gender and decision-making in workplaces.

2. Relationship between occupation and decision-making in workplaces.

$\mathrm{H} 1$ : There is a significant relationship between occupation and decision-making in workplaces.

H0: There is no significant relationship between occupation and decision-making in workplaces.

We have done cross-tabulation via SPSS to check the hypotheses.

Table 13. Cross tabulation - gender $*$ decision-making

\begin{tabular}{|c|c|c|c|c|c|c|c|}
\hline & & & & Decision- & naking & & \\
\hline & & & Alone & $\begin{array}{l}\text { Both, alone and in } \\
\text { groups }\end{array}$ & In groups & $\begin{array}{l}\text { I do not participate } \\
\text { in the decision- } \\
\text { making process }\end{array}$ & Total \\
\hline Gender & male & Quantity & 13 & 5 & 9 & 2 & 29 \\
\hline & & $\%$ in gender & $44.8 \%$ & $17.2 \%$ & $31.0 \%$ & $6.9 \%$ & $100.0 \%$ \\
\hline & female & Quantity & 14 & 2 & 44 & 11 & 71 \\
\hline & & $\%$ in gender & $19.7 \%$ & $2.8 \%$ & $62.0 \%$ & $15.5 \%$ & $100.0 \%$ \\
\hline Total & & Quantity & 27 & 7 & 53 & 13 & 100 \\
\hline & & $\%$ in gender & $27.0 \%$ & $7.0 \%$ & $53.0 \%$ & $13.0 \%$ & $100.0 \%$ \\
\hline
\end{tabular}

Source: The data of survey results analyzed via SPSS

Table 14. Cross tabulation - occupation * decision-making

\begin{tabular}{|c|c|c|c|c|c|c|c|}
\hline & & & \multicolumn{4}{|c|}{ Decision-making } & \multirow[b]{2}{*}{ Total } \\
\hline & & & Alone & $\begin{array}{l}\text { Both, alone } \\
\text { and in } \\
\text { groups }\end{array}$ & In groups & $\begin{array}{l}\text { I do not participate } \\
\text { in the decision- } \\
\text { making process }\end{array}$ & \\
\hline \multirow[t]{8}{*}{ Occupation } & \multirow[t]{2}{*}{ Worker } & Quantity & 13 & 2 & 34 & 11 & 60 \\
\hline & & $\%$ in occupation & $21.7 \%$ & $3.3 \%$ & $56.7 \%$ & $18.3 \%$ & $100.0 \%$ \\
\hline & \multirow{2}{*}{$\begin{array}{l}\text { Middle level } \\
\text { manager }\end{array}$} & Quantity & 7 & 4 & 11 & 2 & 24 \\
\hline & & \% in occupation & $29.2 \%$ & $16.7 \%$ & $45.8 \%$ & $8.3 \%$ & $100.0 \%$ \\
\hline & \multirow{2}{*}{$\begin{array}{l}\text { Lower lever } \\
\text { manager }\end{array}$} & Quantity & 1 & 0 & 6 & 0 & 7 \\
\hline & & $\%$ in occupation & $14.3 \%$ & $0.0 \%$ & $85.7 \%$ & $0.0 \%$ & $100.0 \%$ \\
\hline & \multirow{2}{*}{\begin{tabular}{|l|} 
High level \\
manager
\end{tabular}} & Quantity & 6 & 1 & 2 & 0 & 9 \\
\hline & & $\%$ in occupation & $66.7 \%$ & $11.1 \%$ & $22.2 \%$ & $0.0 \%$ & $100.0 \%$ \\
\hline \multirow{2}{*}{\multicolumn{2}{|c|}{ Total }} & Quantity & 27 & 7 & 53 & 13 & 100 \\
\hline & & $\%$ in occupation & $27.0 \%$ & $7.0 \%$ & $53.0 \%$ & $13.0 \%$ & $100.0 \%$ \\
\hline
\end{tabular}

Source: The data of survey results analyzed via SPSS

Table 15. Chi-Square Testing

\begin{tabular}{|l|c|c|}
\hline \multirow{2}{*}{} & \multicolumn{2}{|c|}{ Pearson Chi-Square } \\
\cline { 2 - 3 } & Value & Approx. Sig. \\
\hline Gender * decision-making & $15.817^{\mathrm{a}}$ & 0.001 \\
\hline Occupation * decision-making & $18.603^{\mathrm{a}}$ & 0.029 \\
\hline
\end{tabular}


In the first case significance level is under 0.05 , this means that we reject the null hypothesis that there is no significant relationship between gender and decision making in workplaces. This means that the relationship is very significant.

In the second case significance level is under 0.05 , this means that we reject the null hypothesis that there is no significant relationship between occupation and decision making in workplaces. This means that the relationship is significant.

The cross-tabulation tables show that women make decisions mainly in groups and men - alone. Workers, lower and middle-level managers make decisions mainly in groups, high-level managers - alone.

\section{Conclusion}

Thus, the survey results show that women tend to make decisions in groups, men - alone. The main characteristics of men during the decision-making process are: analytical thinking, balanced, honesty, confidence, flexibility, high control, tranquility, determination, consulting and competitive thinking.

The main characteristics of women during the decision-making process are: analytical thinking, consulting, honesty and intuitive thinking.

Intuitive thinking, consulting, interpersonal orientation, kindness, impatience were mainly mentioned as qualities more acceptable to women. At the same time qualities like competitive thinking, aggression, ambitious, independence, energetic subjectivity were the main characteristics more associated with men than women.

The survey results also show that workers, lower and middle-level managers make decisions mainly in groups, high-level managers - alone.

The main difficulties to which female leaders face in governance are discriminatory treatment, not obeying, inexperience.

The main reasons why men are appointed to leadership positions according to the respondents are the following: men are not dealing with home affairs and don't go on vacation connected with child birth, they quickly orient and are nimble.

The main stereotypes that hinder women's career advancement are the following: a woman must be obedient; a woman is for staying at home and cooking; a woman is for having a baby; without a man, a woman cannot succeed.

A lot has been done to approve this field, to make equal rights and equal opportunities for men and women, but we should start from the changes in the way of thinking, from people's upbringing. It is better to start these reforms from education, from schools, we should break the stereotypes and create gender-balanced culture. There are various Armenian TV serials and TV programs that preach violence and portrait the image of a man as an abuser, and the image of a woman as a non-working housewife.

The same stereotypes are on media every day, which produces a number of cases where we can see male excellence in every sphere. As a result, women do not hold top positions, especially in the state and local management, they are not able to represent their interests, they mainly don't take part in decision-making processes and they are paid less than men do.

Even during wedding ceremonies in the Armenian church women do not vow that they will have and will hold, from that day forward, for better, worse, richer, poorer, in sickness and health, until death does them part. Instead of proclaiming all of these, the bride as an answer to the priest's require of obedience answers three times that she indeed will be an obedient wife. This example is again one more stereotype, that doesn't give men and women equality.

To sum up, although there are very good legal bases in Armenia for gender equality both on the Constitutional level and everyday regulations, much more must be done to consider different approaches to this very important subject.

\section{References}

1. Caprino, K. (2016). How Decision-Making Is Different Between Men And Women And Why It Matters In Business. Available from: https://www.forbes.com/sites/kathycaprino/2016/05/12/how-decision-making-is- 
different-between-men-and-women-and-why-it-matters-in-business/\#72facd3a4dcd (accessed November 22, 2019).

2. Eagly, A. H., Johannesen-Schmidt, M. C., \& van Engen, M. L. (2003). Transformational, transactional, and laissez-faire leadership styles: A meta-analysis comparing women and men. Psychological Bulletin, 129(4), 569-591. https://doi.org/10.1037/0033-2909.129.4.569.

3. Gender Differences In Decision Making. Available from: https://www.decision-makingconfidence.com/gender-differences-in-decision-making.html (accessed November 22, 2019).

4. Gender strategic plan for the implementation of gender polices in the Republic of Armenia for 2019-2023. Available from:

http://www.mlsa.am/?p=22995\&fbclid=IwAR1nSa1hpAq6tx_OPd3fbzHX7cAF7oGNTWoXPKS2LMu9 1AZwJJO6df9_VBs (accessed December 4, 2019).

5. Gorska, A. (2016). Gender Differences in Leadership. Studia i Materiä̈y, 1/2016(20), 136-144, Wydziaï ZarzÈdzania UW. DOI 10.7172/1733-9758.2016.20.10.

6. Human Development Indices and Indicators (2018). Statistical Update, United Nations Development Programme, New York. Available from:

http://hdr.undp.org/sites/default/files/2018_human_development_statistical_update.pdf

(accessed December 4, 2019).

7. Muyinudeen, B. M. H., Elsadig, M. A. (2008). Gender Differences in Decision-Making Styles of Malaysian Managers. European Journal of Scientific Research, 19(3), 405-415. Available from: https://www.researchgate.net/publication/267764683_Gender_Differences_in_Decision-

Making_Styles_of_Malaysian_Managers (accessed November 22, 2019).

8. Ombaba, K. B. Mwengei (2016). Board Diversity and Financial Performance; Evidence from Kenya. Africa International Journal of Management Education and Governance (AIJMEG) 1(1), 1-15 (C Oasis International Consulting Journals, (ISSN: 2518-0827). Available from: http://www.oircjournals.org/images/journals/BoardDiversity-and-Financial-Performance-1.pdf.

9. Patel, G. (2013). Gender differences in leadership styles and the impact within corporate boards. The Commonwealth Secretariat, Social Transformation Programmes Division. Available from: http://www.cpahq.org/cpahq/cpadocs/Genderdiffe.pdf (accessed November 22, 2019).

10.Shanmugam, M., Amaratunga, R.D.G., Haigh, R.P. Leadership styles: Gender similarities, differences and perceptions. Available from: https://www.irbnet.de/daten/iconda/CIB16523.pdf (accessed November 22, 2019).

11.The Global Gender Gap Report (2018). World Economic Forum, Geneva, pp. 3-73. Available from: http://www3.weforum.org/docs/WEF_GGGR_2018.pdf (accessed December 4, 2019).

12.The low of the Republic of Armenia "The Insurance of Equal Rights and Equal Opportunities for Women and Men" (2013). Available from: www.arlis.am (accessed December 4, 2019).

13.The low of the Republic of Armenia "The Electoral Code of The Republic of Armenia" (2016). Available from: www.arlis.am (accessed December 4, 2019).

14.The state of the Gender Pay Gap in 2018. Available from: https://www.payscale.com/content/whitepaper/Gender-Pay-Gap.pdf (accessed December 4, 2019).

15.Weber, E.U., Blais, A. and Betz, E.N. (2002). A Domain Specific Risk-Attitude Scale: Measuring Risk Perceptions and Risk Behaviors. Journal of Behavioral Decision Making, 15, 263-269. https://doi.org/10.1002/bdm.414.

16.Wing, D. A., Benner, R. S., Petersen, R., Newcomb, R., \& Scott, J. R. (2010). Differences in Editorial Board Reviewer Behavior Based on Gender. Journal of Women's Health, 19(10), 1919-1923. DOI:10.1089/jwh.2009.1904.

17.Women and Men in Armenia 2018 Statistic Booklet. The Statistical Committee of The Republic of Armenia 2018, p. 88. Available from: www.armstat.am (accessed December 4, 2019).

18.Women are still paid less in 2019. Available from: https://www.payscale.com/data/gender-paygap\#section04 (accessed December 4, 2019). 